\title{
PENGARUH KUALITAS PRODUK TERHADAP KEPUTUSAN PEMBELIAN HANDPHONE NOKIA DENGAN CITRA MEREK SEBAGAI PEMEDIASI
}

\author{
Kadek Ayuk Riska Oktavenia ${ }^{1}$ \\ I Gusti Agung Ketut Sri Ardani
}

${ }^{1,2}$ Fakultas Ekonomi dan Bisnis Universitas Udayana (Unud), Bali, Indonesia

E-mail: ayukriska04@gmail.com

\begin{abstract}
ABSTRAK
Studi ini bertujuan untuk untuk mengetahui pengaruh kualitas produk terhadap keputusan pembelian handphone Nokia dengan citra merek sebagai pemediasi. Penelitian ini dilakukan di Kota Denpasar. Jumlah sampel yang diambil sebanyak 99 sampel dengan metode nonprobability sampling, khususnya Accidental sampling atau convenience sampling. Pengumpulan data dilakukan melalui kuesioner dengan skala Likert 1-5. Teknik analisis yang digunakan adalah analisis Partial LeastaSquare (PLS). Hasil studi menemukan bahwa bahwa kualitas produk berpengaruh positif signifikan terhadap keputusan pembelian, citra merek berpengaruh positif signifikan terhadap keputusan pembelian, kualitas produk berpengaruh positif signifikan terhadap citra mereka dan citra merek memediasi pengaruh kualitas produk terhadap keputusan pembelian. Perusahaan harus melakukan market research agar mendapatkan ide atau pertimbangan dalam penambahan spesifikasi yang cocok dan pantas disatukan pada produk handphone Nokia. Dalam pelayanannya, perusahaan perlu bekerja sama dengan berbagai vendor handphone Nokia baik penjualan maupun jasa sparepart, service, dan jaminan asuransi dengan cara memperbanyak kerjasama dengan mereka, dengan ini konsumen akan mudah memperoleh pelayanan yang dibutuhkan.
\end{abstract}

Kata Kunci: kualitas produk, citra merek, keputusan pembelian

\begin{abstract}
This study aims to determine the effect of product quality on Nokia mobile phone purchase decision with brand image as mediator. This research was conducted in Denpasar City. The number of samples taken is 99 samples with nonprobability sampling method, especially Accidental sampling or convenience sampling. The data were collected through questionnaires with Likert scale 1-5. The analysis technique used is Partial Least Square (PLS) analysis. The results of the study found that product quality has a significant positive effect on purchasing decision, brand image hasa significant positive effect on purchasing decision, product quality has a significant positive effect on brand image and brand image mediating the effect of product quality on purchasing decision. Companies should conduct market research to make the product or product specifications suitable and suitable to be incorporated in Nokia mobile phone products. In the service, the company must work together with various vendors of Nokia mobile phones both sales and service spare parts, service, and guarantees by multiplying the cooperation with them, with these consumers will easily obtain the services needed.
\end{abstract}

Keywords: product quality, brand image, purchase decision 


\section{PENDAHULUAN}

Jumlah penduduk Indonesia yang mencapai 250 juta jiwa adalah pasar yang besar. Pengguna handphone Indonesia juga bertumbuh dengan pesat. Lembaga riset digital marketing Emarketer memperkirakan pada 2018 jumlah pengguna aktif handphone di Indonesia lebih dari 100 juta orang. Dengan jumlah sebesar itu, Indonesia akan menjadi negara dengan pengguna aktif handphone terbesar keempat di dunia setelah Cina, India, dan Amerika (www.kominfo.go.id, di akses tanggal 1 oktober 2017).

Kepemilikan handphone bukan satu-satunya syarat yang harus dipenuhi supaya perkembangan teknologi digital berlangsung cepat. DBS Group Research dalam hasil risetnya, Sink or Swim-Business Impact of Digital Technology, menyimpulkan apabila penetrasi teknologi digital sangat dalam dan penggunaannya meluas, dampak teknologi digital akan semakin dirasakan, khususnya di dunia bisnis (www.kominfo.go.id, di akses tanggal 1 oktober 2017).

Industri handphone Indonesia semakin ketat dengan semakin banyak brand yang bersaing di bisnis ini. Nokia merupakan satu dari sekian banyak brand handphone yang beredar di Indonesia. Nokia Corporation adalah produsen peralatan telekomunikasi terbesar di dunia merupakan perusahaan terbesar di Finlandia. (www.id.wikipedia.org, di akses tanggal 1 september 2017).

Ketatnya persaingan di industri handphone membuat penjualan handphone Nokia semakin menurun. Berdasarkan data yang International Data Corporation (IDC) yang dikutip dari www.nokiamob.net memperlihatkan penurunan penjualan 
handphone Nokia dari tahun ke tahun. Pernyataan tersebut dapat dilihat pada gambar statistik berikut.

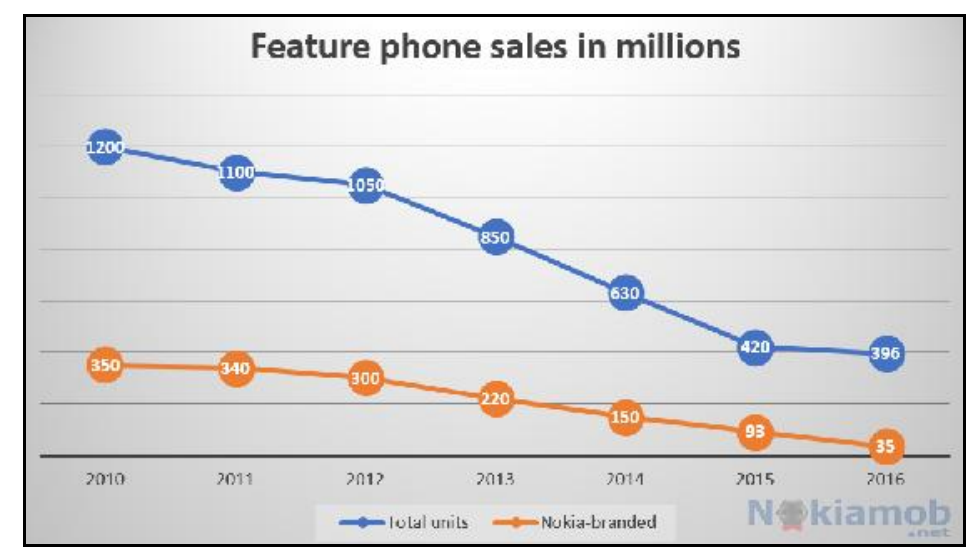

Gambar 1. Penjualan Handphone Nokia dari tahun 2010 sampai 2016 Sumber: www.nokiamob.net, 2017

Gambar 1 menjelaskan bahwa terjadinya penurunan penjualan handphone Nokia dari tahun 2010 sampai dengan tahun 2016 baik dari total unit maupun citra mereknya. Hal tersebut dikarenakan munculnya handphone-handphone lain yang mengakibatkan keputusan pembelian konsumen terhadap Nokia semakin menurun. Menurut Kotler (2009:201) keputusan membeli yaitu beberapa tahapan yang dilakukan oleh konsumen sebelum melakukan keputusan pembelian suatu produk. Keputusan pembelian konsumen dapat dipengaruhi oleh kualitas produk dan citra merek.

Kotler dan Armstrong (2008:75) mengatakan bahwa kualitas produk merupakan senjata strategis yang potensial untuk mengalahkan pesaing. Jadi perusahaan dengan kualitas produk paling baik akan tumbuh dengan pesat, dan dalam jangka panjang perusahaan tersebut akan lebih berhasil dari perusahaan yang lain.Penelitian sebelumnya yang dilakukan oleh Shareef et al. (2008) yang menyatakan bahwa kualitas produk mempengaruhi keputusan pembelian secara 
positif signifikan. Pernyataan tersebut didukung oleh Shaharudin et al. (2011), Ackaradejruangsri (2013), Tamunu dan Ferdinand (2014), dan Kalicharan (2014).

Citra merek adalah sekumpulan asosiasi merek yang terbentuk pada benak konsumen (Mowen, 1995:26). Citra merek mengacu pada skema memori akan sebuah merek yang berisikan interpretasi konsumen atas atribut, kelebihan, penggunaan, situasi, para pengguna, dan karakteristik pemasar dan/atau karakteristik produk/merek tersebut. Citra merek secara langsung mempengaruhi keputusan pembelian konsumen. Pernyataan tersebut didukung oleh Lin (2006), Rajagopal (2006), Horvath (2015), Momani (2015), dan Kurtkoti (2016).

Di satu sisi, hasil penelitian juga ditemukan bahwa kualitas produk secara langsung mampu mempengaruhi citra merek suatu produk. Seperti hasil penelitian Yoo et al. (2000) yang menyatakan bahwa secara positif dan signifikan citra merek dipengaruhi oleh kualitas produk. Beberapa peneliti juga mendukung hasil tersebut seperti yang dilakukan oleh Hanaysha (2014), dan Walter et al. (2003).

Berdasarkan kajian teori dan bukti empiris yang menyatakan bahwa kualitas produk mampu mempengaruhi keputusan pembelian, kualitas produk mampu mempengaruhi merek dan citra merek juga mampu mempengaruhi keputusan pembelian konsumen maka dapat diduga bahwa citra merek memainkan peran sebagai pemediasi pada hubungan antara kualitas produk terhadap keputusan pembelian.

Penelitian ini dilakukan di denpasar karena berdasarkan data yang diperoleh dari badan pusat statistik kota denpasar, jumlah penduduk kota denpasar sebanyak 
897.300 jiwa. Dengan jumlah sebanyak tersebut diharapkan dapat mewakili sampel pengguna handphone khususnya Nokia yang ada di Kota Denpasar.

Secara spesifik, tujuan penelitian ini antara lain: (1) Untuk menjelaskan pengaruh kualitas produk terhadap keputusan pembelian handphone Nokia. (2) Untuk menjelaskan pengaruh citra merk terhadap keputusan pembelian handphone Nokia. (3) Untuk menjelaskan pengaruh kualitas produk terhadap citra merek handphone Nokia. (4) Untuk menjelaskan pengaruh peran citra mereka dalam memediasi hubungan antara kualitas produk dan keputusan pembelian handphone Nokia.

Menurut Garvin dan A. Dale Timpe (dalam Alma, 2011:54) kualitas adalah keunggulan yang dimiliki oleh produk tersebut. Kualitas dalam pandangan konsumen adalah hal yang mempunyai ruang lingkup tersendiri yang berbeda dengan kualitas dalam pandangan produsen saat mengeluarkan suatu produk yang biasa dikenal kualitas sebenarnya. Secara umum, produk adalah pemahaman dari produsen atas sesuatu yang dapat ditawarkan sebagai usaha dalam mendapatkan keuntungan perusahaan yang didapat dari kegiatan pemenuhan kebutuhan konsumen. Menurut Kotler dan Armstrong (2008:76), kualitas didefinisikan sebagai keseluruhan ciri serta sifat barang dan jasa yang berpengaruh pada kemampuan memenuhi kebutuhan yang dinyatakan maupun yang tersirat.

Kualitas produk adalah kemampuan produk untuk memuaskan kebutuhan atau keinginan konsumen (Cannon et al., 2008:28). Definisi lain kualitas produk adalah karakteristik produk atau jasa yang bergantung pada kemampuannya untuk memuaskan kebutuhan konsumen yang dinyatakan atau diimplikasikan (Kotler 
dan Armstrong (2008:27). Menurut Kotler (2009:43), kualitas produk adalah totalitas fitur dan karakteristik produk atau jasa yang bergantung pada kemampuannya untuk memuaskan kebutuhan yang dinyatakan atau tersirat.

Menurut Tjiptono (2009:30), kualitas mencerminkan semua dimensi penawaran produk yang menghasilkan manfaat (benefits) bagi pelanggan. Kualitas suatu produk baik berupa barang atau jasa ditentukan melalui dimensidimensinya. Dimensi kualitas produk menurut Tjiptono (2009:30) adalah: 1) Performance (kinerja), berhubungan dengan karakteristik operasi dasar dari sebuah produk. 2) Durability (daya tahan), yang berarti berapa lama atau umur produk yang bersangkutan bertahan sebelum produk tersebut harus diganti. Semakin besar frekuensi pemakaian konsumen terhadap produk maka semakinbesar pula daya produk. 3) Conformance to specifications (kesesuaian dengan spesifikasi), yaitu sejauh mana karakteristik operasi dasar dari sebuah produk memenuhi spesifikasi tertentu dari konsumen atau tidak ditemukannya cacat pada produk. 4) Features (fitur), adalah karakteristik produk yang dirancang untuk menyempurnakan fungsi produk atau menambah ketertarikan konsumen terhadap produk. 5) Reliability (reliabilitas), adalah probabilitas bahwa produk akan bekerja dengan memuaskan atau tidak dalam periode waktu tertentu. Semakin kecil kemungkinan terjadinya kerusakan maka produk tersebut dapat diandalkan. 6) Aesthetics (estetika), berhubungan dengan bagaimana penampilan produk. 7) Perceived quality (kesan kualitas), merupakan hasil dari penggunaan pengukuran yang dilakukan secara tidak langsung karena terdapat kemungkinan bahwa konsumen tidak mengerti atau kekurangan informasi atas produk yang 
bersangkutan. 8) Serviceability, meliputi kecepatan dan kemudahan untuk direparasi, serta kompetensi dan keramahtamahan staf layanan.

Citra menurut Kotler (2009:46) adalah sejumlah keyakinan, ide, dan kesan yang dipegang oleh seseorang tentang sebuah objek. Sedangkan menurut Ferrinadewi (2008) citra merek adalah persepsi tentang merek yang merupakan refleksi memori konsumen akan asosiasinya pada merek tersebut.

Menurut Tjiptono (2009:37) citra merek (brand image) yakni deskripsi tentang asosiasi dan keyakinan konsumen terhadap merek tertentu. Kesimpulannya bahwa citra merek adala persepsi dan keyakinan konsumen terhadap merek tertentu yang merupakan refleksi memori konsumen akan asosiasinya pada merek tersebut.

Menurut Kotler (2009:47), di dalam citra merek terdapat 3 faktor yang merangkai sebuah citra merek, antara lain: 1) Brand Favorability adalah kesukaan terhadap brand, kepercayaan dan perasaan bersahabat dengan suatu brand, serta akan sulit bagi brand, lain untuk dapat menarik konsumen yang sudah mencintai brand, hingga pada tahap ini. 2) Brand Strength adalah seberapa sering seseorang terpikir tentang informasi suatu brand, ataupun kualitas dalam memproses segala informasi yang diterima konsumen. 3) Brand Uniqueness adalah membuat kesan unik dan perbedaan yang berarti diantara brand lain serta membuat konsumen tidak mempunyai alasan untuk tidak memilih brand tersebut.

Perilaku konsumen selalu berubah dan bergerak sepanjang waktu. Perilaku konsumen merupakan faktor utama konsumen dalam membuat keputusan- 
keputusan pembelian serta bagaimana mereka menggunakan dan mengatur pembelian barang atau jasa.

Keputusan pembelian menurut Schiffman dan Kanuk (2004:329) adalah pemilihan dari dua atau lebih alternatif pilihan keputusan pembelian yang artinya bahwa seseorang dapat membuat keputusan, haruslah tersedia beberapa alternatif pilihan. Pengambilan keputusan adalah suatu pemikiran yang dilakukan setelah mengevaluasi beberapa pilihan. Dengan kata lain, agar seseorang membuat keputusan maka harus ada pilihan alternatif yang tersedia.

Ada beberapa peranan yang mungkin dimainkan orang dalam mengambil keputusan untuk membeli suatu barang, yaitu: 1) Orang yang mengambil inisiatif (initiator). 2) Orang yang mempengaruhi (influencer) 3) Orang yang mengambil keputusan (decider) 4) Orang yang membeli (buyer) 5) Orang yang memakai (user). Tahap-tahap dalam proses keputusan membeli menurut Kotler (2009:357) adalah sebagai berikut: 1) Pengenalan masalah. 2) Pencarian informasi. 3) Penilaian alternatif. 4) Keputusan membeli.

Dalam pembelian handphone kualitas adalah faktor penentu utama keputusan pembelian konsumen. Beberapa penelitian terdahulu menunjukkan bahwa kualitas produk mempengaruhi keputusan pembelian konsumen. Seperti penelitian yang dilakukan oleh Shareef et al. (2008) yang menyatakan bahwa kualitas produk mempengaruhi keputusan pembelian secara positif signifikan. Pernyataan tersebut didukung oleh Shaharudin et al. (2011) yang sependapat bahwa kualitas produk memainkan peran penting dalam mengambil keputusan suatu pembelian. Hasil penelitian serupa juga ditunjukkan oleh Ackaradejruangsri 
(2013), Tamunu dan Ferdinand (2014), dan Kalicharan (2014). Berdasarkan uraian tersebut maka dapat dirumuskan hipotesis pertama sebagai berikut:

$\mathrm{H}_{1}$ : $\quad$ Kualitas produk berpengaruh positif dan signifikan terhadap keputusan pembelian handphone Nokia.

Citra menurut Kotlera (2009:46) adalah sejumlah keyakinan, ide, dan kesan yang dipegang oleh seseorang tentang sebuah objek. Menurut Ferrinadewi (2008) citra merek adalah persepsi tentang merek yang merupakan refleksi memori konsumen akan asosiasinya pada merek tersebut. Sedangkan menurut Tjiptono (2009:37) citra merek (brand image) yakni deskripsi tentang asosiasi dan keyakinan konsumen terhadap merek tertentu. Kesimpulannya bahwa citra merek adalah persepsi dan keyakinan konsumen terhadap merek tertentu yang merupakan refleksi memori konsumen akan asosiasinya pada merek tersebut.

Berdasarkan penelitian terdahulu, citra merek mempengaruhi keputusan pembelian konsumen. Seperti halnya penelitian yang dilakukan oleh Lin (2006) yang mengatakan bahwa citra merek secara positif signifikan mempengaruhi keputusan pembelian konsumen. Peneliti lain yang menyatakan bahwa citra merek mempengaruhi keputusan pembelian konsumen ditunjukkan oleh Rajagopal (2006), Horvath (2015), Momani (2015), dan Kurtkoti (2016). Berdasarkan uraian tersebut maka dapat dirumuskan hipotesis kedua sebagai berikut:

$\mathrm{H}_{2}$ : Citra merek berpengaruh positif dan signifikan terhadap keputusan pembelian handphone Nokia.

Berdasarkan penelitian terdahulu, kualitas produk mempengaruhi citra merek. Seperti halnya penelitian yang dilakukan oleh Yoo et al. (2000), dan 
Walter et al. (2000) yang menyatakan bahwa secara positif dan signifikan citra merek dipengaruhi oleh kualitas produk. Pernyataan tersebut didukung oleh Megarita dan Tony (2014) bahwa kualitas produk mampu mempengaruhi citra merek secara signifikan. Beberapa peneliti juga mendukung hasil tersebut seperti yang dilakukan oleh Hanaysha (2014), adan Sihabudin (2015). Berdasarkan uraian tersebut maka dapat dirumuskan hipotesis ketiga sebagai berikut:

$\mathrm{H}_{3}$ : Kualitas produk berpengaruh positif dan signifikan terhadap citra merek handphone Nokia.

Berdasarkan penelitian terdahulu yang dilakukan oleh Shareef et al. (2008), Shaharudin et al. (2011), Ackaradejruangsri (2013), Tamunu dan Ferdinand (2014), serta Kalicharan (2014) yang menyatakan bahwa kualitas produk mempengaruhi keputusan pembelian secara positif signifikan. Penelitian Lin (2006), Rajagopal (2006), Horvath (2015), Momani (2015), dan Kurtkoti (2016) yang mengatakan bahwa citra merek secara positif signifikan mempengaruhi keputusan pembelian konsumen. Serta penelitian Yoo et al. (2000), dan Walter et al. (2000), Megarita dan Tony (2014), Hanaysha (2014), dan Sihabudin (2015) yang menyatakan bahwa secara positif dan signifikan citra merek dipengaruhi oleh kualitas produk. Maka citra merek memainkan peran mediasi diantara pengaruh kualitas produk terhadap keputusan pembelian.

$\mathrm{H}_{4}$ : Citra merk memediasi pengaruh kualitas produk terhadap keputusan pembelian handphone Nokia.

\section{METODE PENELITIAN}

Jenis penelitian merupakan penelitian asosiatif kausal (sebab-akibat) yang bertujuan untuk mengetahui pengaruh variable dependen terhadap variabel 
independen menggunakan teknik analisis kuantitatif. Ruang lingkup penelitian ini adalah bidang manajemen pemasaran, khususnya mengenai peran citra merek sebagai mediasi pengaruh kualias produk terhadap keputusan pembelian konsumen. Penelitian ini dilakukan di Kota Denpasar dengan jumlah penduduk sebanyak 897.300 dimana sebagian besarnya adalah pengguna handphone.

Populasi dari penelitian ini adalah seluruh masyarakat pengguna handphone Nokia di Kota Denpasar. Menurut Malhotra (2012:647) untuk memperoleh hasil yang baik ukuran sampel responden yang di ambil untuk mengisi kuesioner dapat ditentukan paling sedikit 5-10 kali jumlah variabel yang diteliti. Pada penelitian ini, jumlah sampel yang diambil adalah 99 sampel. Instrumen penelitian menggunakan kuesioner dengan menggunakan skala likert dimana variasi skor antara (5) sangat setuju (1) sangat tidak setuju.

Kualitas produk diukur menggunakan 4 indikator yang digunakan oleh Nasution (2008:38), citra merek menggunakan indikator yang dikemukakan oleh Randheer (2012) dalam Irawan dan Edwin (2013) menyatakan bahwa citra merek memiliki 3 indikator, sedangkan keputusan pembelian diukur dengan 4 indikator yang diadopsi dari penelitian Anggar (2012). Teknik analisis yang digunakan pada penelitian ini adalah Partial Least Square (PLS), dengan bantuan software SmartPLS 2.

\section{HASIL DAN PEMBAHASAN}

Pembentukan Kota Denpasar pada mulanya berupa Kota Administratif. Kota Administratif merupakan sebuah wilayah administratif di Indonesia yang dipimpin oleh Walikota Administratif. Keberadaan Kota Administratif diatur oleh 
Undang-Undang Republik Indonesia Nomor 5 Tahun 1974 tentang Pokok-Pokok Pemerintahan Daerah. Kota Administratif bukanlah daerah otonom sebagaimana Kotamadya atau kota, dan karena tidak memiliki Dewan Perwakilan Rakyat Daerah. Walikota Administratif bertanggung jawab kepada Bupati Kabupaten induknya. Sejak diberlakukannya Undang-Undang Republik Indonesia Nomor 22 Tahun 1999, di Indonesia tidak dikenal lagi istilah Kota Administratif karena pembagian Provinsi hanya terdiri atas Kabupaten dan kota. Akibatnya Kota Administratif harus berubah status menjadi kota atau bergabung kembali dengan Kabupaten induknya.

Kota Denpasar adalah Ibukota Provinsi Bali yang mengalami pertumbuhan dan perkembangan disegala bidang yang terus meningkat, memberikan pengaruh besar terhadap kota sendiri. Kota Denpasar yang merupakan Ibukota Kabupaten Daerah Tingkat II Badung dan sekaligus merupakan Ibukota Provinsi Daerah Tingkat I Bali mengalami pertumbuhan demikian pesatnya. Pertumbuhan penduduknya rata-rata 4,05\% pertahun dengan pertumbuhan diberbagai sektor, sehingga memberi pengaruh besar terhadap Kota Denpasar, pada akhirnya menimbulkan berbagai permasalahan yang harus diselesaikan oleh pemerintah Kota Administratif. Berdasarkan kondisi objektif dan berbagai pertimbangan antara Tingkat I Bali dan Tingkat II Badung telah dicapai kesepakatan untuk meningkatkan status Kota Administratif Denpasar menjadi Kota Denpasar.

Kota Denpasar lahir tanggal 15 Januari 1992 berdasarkan UndangUndang Nomor I Tahun 1992 tentang pembentukan Kota Denpasar dan telah diresmikan oleh Menteri Dalam Negeri pada tanggal 27 Februari 1992. Pemerintahan di 
Daerah Tingkat I Bali, Kabupaten Daerah Tingkat II Badung dan juga Kota Denpasar. Provinsi Daerah Tingkat I Bali merupakan pengembangan yang dulunya terdiri atas 8 (delapan) Daerah Tingkat II sekarang menjadi 9 (Sembilan) Daerah Tingkat II. Sedangkan Kabupaten Badung telah kehilangan sebagian wilayah potensi yang terkandung didalamnya. Sementara bagi Kota Denpasar merupakan babak baru dalam penyelenggaraan pemerintahan dan pembangunan yang merupakan Daerah Tingkat II terbungsu diwilayah Provinsi Daerah Tingkat I Bali.

Kota Denpasar mengalami perkembangan pesat secara fisik maupun non fisik. Di jadikannya Kota Denpasar sebagai Ibukota Provinsi Bali, berarti segala kegiatan pemerintahan berlangsung di wilayah Kota Denpasar. Berdirinya Universitas Udayana Tahun 1962 juga menjadi penyebab semakin pesatnya perkembangan Kota Denpasar, karena dengan demikian Kota Denpasar juga menjadi pusat pendidikan yang akan menjadi penampung para pelajar untuk melanjutkan pendidikan ke Perguruan Tinggi. Keterikatan masyarakat dengan Puri dapat kita lihat di Kota Denpasar sebagai kota budaya, dimana masyarakat terikat dengan empat Puri besar yang berperan penting, yaitu Puri Denpasar, Puri Pemecutan, Puri Satria, Puri Kesiman. Terdapat dua Puri yang memainkan peranan penting yaitu Puri Kesiman dan Puri Denpasar. Melalui kekuasaan ini kemudian Kota Denpasar berkembang baik dalam aspek ekonomi, politik, sosial budaya dan pendidikan (Ardhana, 2005:412).

Kota Denpasar secara administratif wilayah memiliki 4 kecamatan dan 43 Desa/Kelurahan. Kecamatan Denpasar Selatan terdiri dari 10 Desa. Denpasar 
Timur 11 Desa/Kelurahan. Denpasar Barat 11 Desa/Kelurahan. Denpasar Utara 11 Desa/Kelurahan. Letak geografis Kota Denpasar berada ditengah-tengah Pulau Bali menjadikan Kota Denpasar sebagai titik sentral berbagai kegiatan serta sekaligus sebagai pusat distribusi barang dan jasa. Disamping itu, sebagai Ibukota Provinsi Bali. Kota Denpasar sudah tentu sebagai pusat pemerintahan, pendidikan, dan perekonomian di Provinsi Bali.

Kota Denpasar terletak antara $08^{\circ} 35^{\circ} 31^{\circ}-08^{\circ} 44^{\circ} 49^{\circ}$ Lintang Selatan dan $115^{\circ} 10^{\circ} 23^{\circ}-115^{\circ} 16^{\circ} 27^{\circ}$ Bujur Timur. Batas wilayah Kota Denpasar sebagian besar berbatasan dengan Kabupaten Badung yaitu sebelah utara, barat dan selatan, sedangkan sebelah timur adalah Kabupaten Gianyar dan Selat Lombok. Secara umum Kota Denpasar merupakan daratan rendah dengan ketinggian berkisar antara 0-75m diatas permukaan laut. Akses jalan di Kota Denpasar hingga Tahun 2013 jalan utama kota sangat baik dan terawat dengan bagus. Dimana sebagian besar jalan utama sudah di aspal dengan tujuan mempermudah warga masyarakat untuk mengakses berbagai tempat tujuan mereka Deskripsi Variabel Penelitian digambarkan secara rinci karakteristik responden disajikan pada Tabel 1.

Berdasarkan Tabel 1 hasil penelitian menunjukkan rata-rata konstruk variabel kualitas produk sebesar 3,45. Hal ini menunjukkan sebagian besar responden setuju bahwa handphone nokia memiliki kualitas produk yang tinggi. 
Tabel 1.

Deskripsi Variabel Penelitian Kualitas Produk

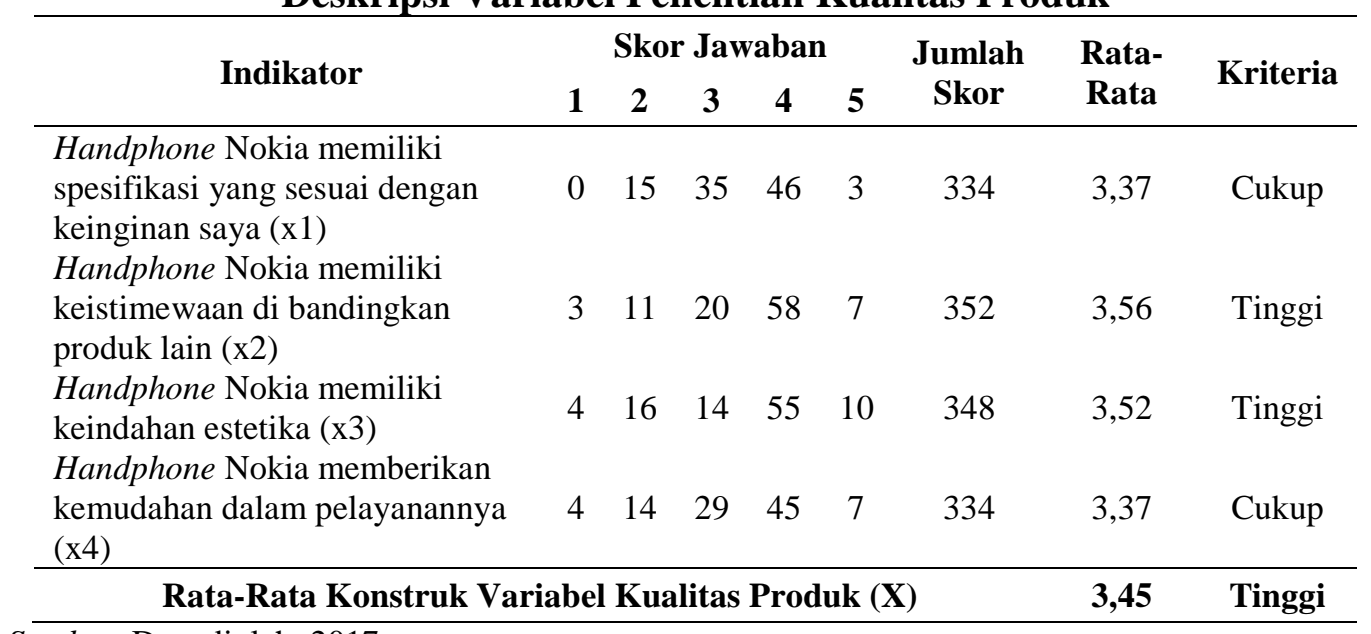

Sumber: Data diolah, 2017

Keistimewaan produk (X2) dan keindahan estetika produk (X3) memiliki nilai rata-rata diatas konstruk kualitas produk, yaitu sebesar 3,56 dan 3,52. Hal ini menunjukkan bahwa kualitas produk handphone Nokia lebih besar pada keistimewaan serta keindahan estetikanya.

Konstruk citra merek dalam penelitian ini terdiri dari tiga indikator. Hasil analisis deskriptif mengenai konstruk citra merek ditunjukkan dalam Tabel 2:

Tabel 2.

Deskripsi Konstruk Variabel Citra Merek

\begin{tabular}{|c|c|c|c|c|c|c|c|c|}
\hline \multirow{2}{*}{ Indikator } & \multicolumn{5}{|c|}{ Skor Jawaban } & \multirow{2}{*}{$\begin{array}{l}\text { Jumlah } \\
\text { Skor }\end{array}$} & \multirow{2}{*}{$\begin{array}{l}\text { Rata- } \\
\text { Rata }\end{array}$} & \multirow{2}{*}{ Kriteria } \\
\hline & 1 & 2 & 3 & 4 & 5 & & & \\
\hline $\begin{array}{l}\text { Handphone Nokia merupakan } \\
\text { produk yang sangat bernilai (m1) }\end{array}$ & 8 & 11 & 27 & 47 & 6 & 329 & 3.32 & Cukup \\
\hline $\begin{array}{l}\text { Handphone Nokia memiliki citra } \\
\text { merek yang bagus (m2) }\end{array}$ & 4 & 14 & 24 & 52 & 5 & 337 & 3.40 & Cukup \\
\hline $\begin{array}{l}\text { Merek handphone Nokia mudah } \\
\text { untuk saya kenali (m3) }\end{array}$ & 1 & 21 & 24 & 41 & 12 & 339 & 3.42 & Cukup \\
\hline \multicolumn{7}{|c|}{ Rata-Rata Konstruk Variabel Citra Merek (M) } & 3.38 & Cukup \\
\hline
\end{tabular}

Sumber: Data diolah, 2017

Berdasarkan Tabel 2, hasil penelitian menunjukkan bahwa konstruk citra merek secara keseluruhan dinilai oleh responden yang didasarkan pada persepsi 
rata-rata sebesar 3,38, yang berarti memiliki kriteria cukup. Hal ini menunjukkan bahwa perusahaan belum mampu secara maksimal menciptakan citra merek yang tinggi untuk produk handphone Nokia

Hasil analisis deskriptif mengenai konstruk keputusan pembelian ditunjukkan dalam Tabel 3.

Tabel 3.

Deskripsi Konstruk Variabel Keputusan Pembelian

\begin{tabular}{|c|c|c|c|c|c|c|c|c|}
\hline \multirow{2}{*}{ Indikator } & \multicolumn{5}{|c|}{ Skor Jawaban } & \multirow{2}{*}{$\begin{array}{l}\text { Jumlah } \\
\text { Skor }\end{array}$} & \multirow{2}{*}{$\begin{array}{l}\text { Rata- } \\
\text { Rata }\end{array}$} & \multirow{2}{*}{ Kriteria } \\
\hline & 1 & 2 & 3 & 4 & 5 & & & \\
\hline $\begin{array}{l}\text { Sayaamerasa yakin jika membeli } \\
\text { produk handphone Nokia (y1) }\end{array}$ & 3 & 20 & 17 & 43 & 16 & 346 & 3.49 & Tinggi \\
\hline $\begin{array}{l}\text { saya akan mencari informasi lebih } \\
\text { lanjut sebelum membeli } \\
\text { handphone Nokia (y2) }\end{array}$ & 3 & 15 & 30 & 40 & 11 & 338 & 3.41 & Cukup \\
\hline $\begin{array}{l}\text { Saya melakukan sebuah } \\
\text { perencanaan terlebih dahulu } \\
\text { untuk membeli sebuah } \\
\text { handphone (y3) }\end{array}$ & 3 & 20 & 15 & 46 & 15 & 347 & 3.51 & Tinggi \\
\hline $\begin{array}{l}\text { Saya akan membeli sebuah } \\
\text { handphone yang sesuai dengan } \\
\text { keinginan saya (y4) }\end{array}$ & 4 & 16 & 22 & 46 & 11 & 341 & 3.44 & Tinggi \\
\hline \multicolumn{7}{|c|}{ Rata-Rata Konstruk Variabel Citra Merek (M) } & 3.46 & Tinggi \\
\hline
\end{tabular}

Sumber: Data diolah, 2017

Berdasarkan Tabel 3, hasil penelitian menunjukkan bahwa konstruk keputusan pembelian secara keseluruhan dinilai oleh responden yang didasarkan pada persepsi rata-rata sebesar 3,46, yang berarti memiliki kriteria tinggi. Hal ini menunjukkan bahwa perusahaan sudah mampu menciptakan masyarakat memiliki keputusan pembelianyang tinggi untuk produk handphone Nokia.

Hasil uji outer model menunjukkan bahwa seluruh indikator variable dapat dikatakan valid dan reliable jika outer loadings diatas 0,50 , berikut dapat dilihat pada Tabel 4. Tabel 4 menjelaskanbahwa seluruh konstruk indikator memiliki outer loadings di atas 0,50 , maka konstruk memiliki data yang baik. 
Tabel 4.

Uji Outer Model

\begin{tabular}{|c|c|c|}
\hline & Variabel, Indikator & $\begin{array}{r}\text { Outer } \\
\text { Loading }\end{array}$ \\
\hline \multicolumn{3}{|c|}{ Keputusan Pembelian (Y) } \\
\hline Y1 & Saya merasa yakin jika membeli produk handphone Nokia & 0,936 \\
\hline $\mathrm{Y} 2$ & $\begin{array}{l}\text { Sebelum saya membeli sebuah handphone, saya akan mencari informasi lebih } \\
\text { lanjut tentang handphone tersebut }\end{array}$ & 0,927 \\
\hline $\mathrm{Y} 3$ & $\begin{array}{l}\text { Saya melakukan sebuah perencanaan terlebih dahulu untuk membeli sebuah } \\
\text { handphone }\end{array}$ & 0,94 \\
\hline Y4 & Saya akan membeli sebuah handphone yang sesuai dengan keinginan saya & 0,902 \\
\hline \multicolumn{3}{|c|}{ Citra Merek (M) } \\
\hline M1 & Handphone Nokia merupakan produk yang sangat bernilai & 0,934 \\
\hline M2 & Handphone Nokia memiliki citra merek yang bagus karena kualitas produknya & 0,936 \\
\hline M3 & Merek handphone Nokia mudah untuk saya kenali dan saya ingat & 0,898 \\
\hline \multicolumn{3}{|c|}{ Kualitas Produk (X) } \\
\hline $\mathrm{X} 1$ & Handphone Nokia memiliki spesifikasi yang sesuai dengan keinginan saya & 0,921 \\
\hline $\mathrm{X} 2$ & Handphone Nokia memiliki keistimewaan di bandingkan produk lain & 0,894 \\
\hline $\mathrm{X} 3$ & Handphone Nokia memiliki keindahan estetika & 0,942 \\
\hline $\mathrm{X} 4$ & Handphone Nokia memberikan kemudahan dalam pelayanannya & 0,916 \\
\hline
\end{tabular}

Dalam model struktural ini, terdapat dua variabel terikat, yaitu: citra merek

(M) dan keputusan pembelian (Y). Adapun koefisien determinasi $\left(\mathrm{R}^{2}\right)$

dari masing-masing variabel terikat dapat disajikan dalam Tabel 5 berikut.

Tabel 5.

Nilai $R$-square Variabel Terikat

\begin{tabular}{lcc}
\hline & Variabel & $\boldsymbol{R}$-square \\
\hline Citra Merek (M) & 0,791 \\
Keputusan Pembeliana (Y) & 0,661 \\
\hline
\end{tabular}

Sumber: Hasil pengolahan data, 2017

Untuk mengukur seberapa baik nilai observasi dihasilkan oleh model dan juga estimasi parameternya, maka perlu menghitung $Q$-square sebagai berikut:

$$
\begin{aligned}
& \mathrm{Q}^{2}=1-\left(1-\left(\mathrm{R}_{1}\right)^{2}\right)\left(1-\left(\mathrm{R}_{2}\right)^{2}\right) \\
& =\quad 1-\left(1-(0,791)^{2}\right)\left(1-(0,661)^{2}\right) \\
& =\quad 0,789
\end{aligned}
$$

Besaran $\mathrm{Q}^{2}$ memiliki nilai dengan rentang $0<\mathrm{Q}^{2}<1$, dimana semakin mendekati 1 berarti model semakin baik. Hasil perhitungan tersebut didapat nilai 
$\mathrm{Q}^{2}$ adalah sebesar 0,789 , sehingga dapat disimpulkan bahwa model memiliki predictive relevance yang baik $\left(\mathrm{Q}^{2}=0,789>0\right)$.

Masrun dalam Sugiyono (2008:188) menyatakan variabel-variabel terukur dikatakan valid jika muatan faktornya (r) $\geq 0,3$ (untuk $\mathrm{n}=30$, pada $\alpha=5 \%$ ) atau model dikatakan baik jika AVE masing-masing variabel nilainya lebih besar dari 0,50. Hasil validitas konstruk dapat dilihat pada discriminant validity yang dijabarkan pada tabel 6 berikut.

Tabel 6. Discriminant Validity

\begin{tabular}{lrrrrr}
\hline \multicolumn{1}{c}{ Variabel Penelitian } & AVE & $\begin{array}{c}\text { Akar } \\
\text { AVE }\end{array}$ & $\begin{array}{c}\text { Citra merek } \\
\text { (M) }\end{array}$ & $\begin{array}{c}\text { Korelasi } \\
\text { Keputusan } \\
\text { pembelian (Y) }\end{array}$ & $\begin{array}{c}\text { Kualitas } \\
\text { produk (X) }\end{array}$ \\
\hline Citraamerek (M) & 0,852 & $\mathbf{0 , 9 2 3}$ & 1,000 & 0,782 & 0,889 \\
Keputusan pembelian (Y) & 0,858 & $\mathbf{0 , 9 2 6}$ & & 1,000 & 0,797 \\
Kualitas produk (X) & 0,844 & $\mathbf{0 , 9 1 9}$ & & & 1,000 \\
\hline Sumber: Hasil pengolahan data, 2017 & & & &
\end{tabular}

Berdasarkan Tabel 6 dapat dijelaskan bahwa nilai akar AVE konstruk citra merek (M) yaitu 0,923, nilai akar AVE konstruk keputusan pembelian (Y) yaitu 0,926, dan nilai akar AVE konstruk kualitas produk (X) yaitu 0,919, lebih besar dari korelasi variabel laten dengan konstruk lainnya. Dengan demikian, semua konstruk dalam model yang diuji memenuhi criteria discriminant validity. Disamping itu, hasil output menunjukkan bahwa nilai AVE seluruh variable lebih besar dari 0,50 sehingga model dapat dikatakan baik.

Uji reliabilitas konstruk yang diukur dengan dua kriteria yaitu composite reliability dan cronbachs alpha. Konstruk dinyatakan reliabel jika nilai composite reliability maupun cronbachs alpha diatas 0,70 . 
Tabel 7.

Composite Reliability

\begin{tabular}{lccc}
\hline \multicolumn{1}{c}{ Variabel } & $\begin{array}{c}\text { Composite } \\
\text { Reliability }\end{array}$ & $\begin{array}{c}\text { Cronbachs } \\
\text { Alpha }\end{array}$ & Keterangan \\
\hline Kualitas Produk (X) & 0,956 & 0,938 & Reliabel \\
Citra Merek (M) & 0,945 & 0,913 & Reliabel \\
KeputusanaPembelian (Y) & 0,96 & 0,945 & Reliabel \\
\hline
\end{tabular}

Sumber: Hasil pengolahanadata, 2017

Tabel 7 menunjukkan bahwa composite reliability maupun cronbachs alpha semuanya diatas 0,70 , dengan demikian, dapat dijelaskan bahwa seluruh konstruk memiliki reliabilitas yang baik.

Penelitian ini menggunakan analisis Partial Least Square (PLS) untuk melakukan uji hipotesis yang telah dikemukakan sebelumnya yang dapat dilihat pada Gambar 1.

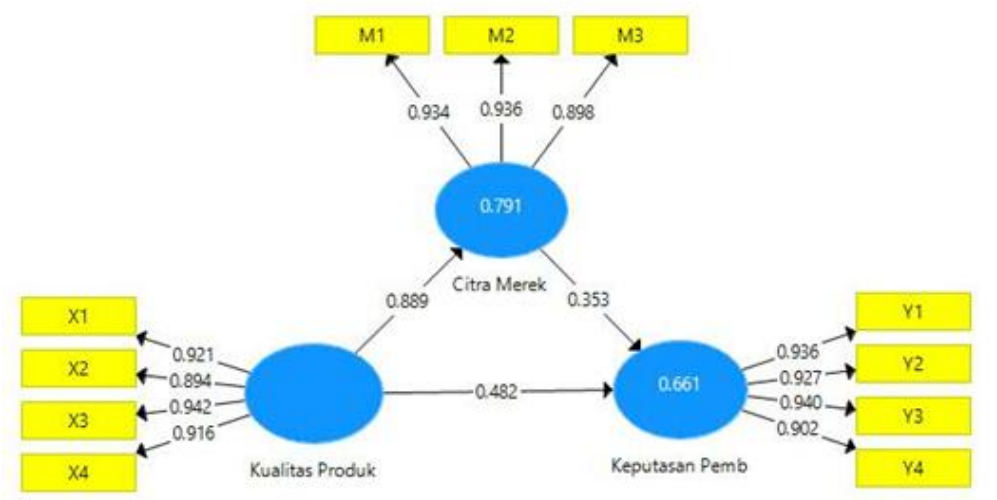

\section{Gambar 2. Struktur Hubungan Kausal}

Berdasarkan Tabel 8 dapat disimpulkan bahwa kualitas produk berpengaruh langsung terhadap keputusan pembelian dengan koefisien sebesar 0,482 (nilai t statistics $>\mathrm{t}$ kritis1,96), kualitas produk berpengaruh langsung terhadap citra merek dengan koefisien sebesar 0,889 (nilai t statistics $>\mathrm{t}$ kritis 1,96 ), serta citra merek berpengaruh langsung terhadap keputusan pembelian dengan koefisien sebesar 0,353 (nilai t statistics $>\mathrm{t}$ kritis1,96). 
Tabel 8.

Path Coefficients

\begin{tabular}{lcccc}
\hline \multicolumn{1}{c}{ KorelasiaAntar Variabel } & $\begin{array}{c}\text { Koefisien } \\
\text { Korelasi }\end{array}$ & t Statistics & $\begin{array}{c}\boldsymbol{p} \\
\text { Values }\end{array}$ & Keterangan \\
\hline $\begin{array}{l}\text { Kualitas produk }(\mathrm{X}) \rightarrow \text { Keputusan } \\
\text { pembelian (Y) }\end{array}$ & 0,482 & 3,961 & 0,000 & Signifikan \\
$\begin{array}{l}\text { Kualitas produk }(\mathrm{X}) \rightarrow \text { Citra merek }(\mathrm{M}) \\
\begin{array}{l}\text { Citra merek }(\mathrm{M}) \rightarrow \text { Keputusan } \\
\text { pembelian }(\mathrm{Y})\end{array}\end{array}$ & 0,889 & 37,891 & 0,000 & Signifikan \\
\hline
\end{tabular}

Sumber: Data diolah, 2018

Uji peran mediasi citra merek pada pengaruh keadilan organisasional terhadap komitmen organisasional dengan memeriksa indirect effects yang merupakan output SmartPLS seperti tersaji pada Tabel 9. Berdasarkan Tabel 9, dapat dijelaskan bahwa nilai $t$ Statistics lebih besar dari nilai t tabel (2,578 > 1,96), maka citra merek secara signifikan memediasi kualitas produk terhadap keputusan pembelian.

Tabel 9.

Indirect Effects

\begin{tabular}{lcccc}
\hline \multicolumn{1}{c}{ Korelasi Antar Variabel } & $\begin{array}{c}\text { Koefisien } \\
\text { Korelasi }\end{array}$ & t Statistics & $\begin{array}{c}\boldsymbol{p} \\
\text { Values }\end{array}$ & Keterangan \\
\hline $\begin{array}{l}\text { Kualitas produk }(\mathrm{X}) \rightarrow \text { Citra } \\
\text { merek }(\mathrm{M}) \rightarrow \text { Keputusan } \\
\text { pembelian }(\mathrm{Y})\end{array}$ & 0,314 & 2,836 & 0,005 & Signifikan \\
$\begin{array}{l}\text { Sumber: Hasil pengolahan data, 2017 } \\
\text { Sumber }\end{array}$ & & & & \\
\hline
\end{tabular}

Hasil analisis menunjukkan bahwa kualitas produk berpengaruh positif dan signifikan terhadap keputusan pembelian. Hal ini memiliki makna bahwa semakin tinggi kualitas produk yang ditawarkan handphone Nokia kepada masyarakat, maka semakin tinggi keputusan mereka untuk membeli produk tersebut. Secara keseluruhan kualitas produk handphone Nokia cukup tinggi, karena produk tersebut memiliki keistimewaan yang tidak ada produk handphone yang lainnya. 
Keindahan estetika handphone Nokia juga merupakan keunggulan produk tersebut.

Hasil ini sesuai dengan beberapa penelitian terdahulu yaitu: Shareef et al. (2008), Shaharudin et al. (2011), Ackaradejruangsri (2013), Tamunu dan Ferdinand (2014), dan Kalicharan (2014) yang menyimpulkan bahwa terdapat pengaruh positif dan signifikan antara kualitas produk dengan keputusan pembelian.

Hasil analisis menunjukkan bahwa citra merek berpengaruh positif signifikan terhadap keputusan pembelian. Hal tersebut menjelaskan bahwa citra merek terbukti mampu meningkatkan keputusan pembelian yang dilakukan oleh konsumen. Temuan ini dapat diartikan bahwa apabila perusahaan mampu meningkatkan citra merek handphone Nokia, maka keputusan pembelian yang dilakukan oleh konsumen akan semakin meningkat.

Hasil ini sesuai dengan beberapa penelitian terdahulu yaitu Yoo et al. (2000), Walter et al. (2000), Megarita dan Tony (2014), dan Hanaysha (2014), serta Sihabudin (2015) yang menyimpulkan bahwa terdapat pengaruh positif dan signifikan antara kepuasan kerja dengan komitmen organisasional.

Hasil analisis menunjukkan bahwa kualitas produk berpengaruh positif dan signifikan terhadap citra merek. Hal tersebut menjelaskan bahwa kualitas produk terbukti mampu meningkatkan citra merek di benak. Temuan ini dapat diartikan bahwa apabila kualitas produk handphone Nokia ditingkatkan oleh perusahaan, makaaakan mampu memberikan kontribusi yang signifikan untuk meningkatkan citra daripada merek produk tersebut. 
Hasil ini sesuai dengan beberapa penelitian terdahulu yaitu: Lin (2006), Rajagopal (2006), Horvath (2015), Momani (2015), dan Kurtkoti (2016) yang menyimpulkan bahwa terdapat pengaruh positif dan signifikan antara kualitas produk dengan keputusan pembelian.

Hasil pengujian hipotesis membuktikan bahwa kualitas produk berpengaruh positif dan signifikan terhadap keputusan pembelian, kualitas produk berpengaruh positif dan signifikan terhadap citra merek, dan citra merek berpengaruh positif dan signifikan terhadap keputusan pembelian, maka dapat dijelaskan bahwa citra merek berperan sebagai mediasi pengaruh kualitas produk terhadap keputusan pembelian. Hal tersebut menunjukkan bahwa kualitas produk dan citra merek menjadi factor penting dalam menentukan keputusan pembelian yang dilakukan oleh konsumen. Melalui upaya kolaborasi dengan peningkatan aspek aspek kualitas produk, maka kecenderungan menurunnya keputusan pembelian dapat diminimalisir.

Hasil ini sesuai dengan penelitian terdahulu seperti: Shareef et al. (2008), Shaharudin et al. (2011), Ackaradejruangsri (2013), Tamunu dan Ferdinand (2014), serta Kalicharan (2014) yang menyatakan bahwa kualitas produk mempengaruhi keputusan pembelian secara positif signifikan. Penelitian Lin (2006), Rajagopal (2006), Horvath (2015), Momani (2015), dan Kurtkoti (2016) yang mengatakan bahwa citra merek secara positif signifikan mempengaruhi keputusan pembelian konsumen. Serta penelitian Yoo et al. (2000), dan Walter et al. (2000), Megarita dan Tony (2014), Hanaysha (2014), dan Sihabudin (2015) 
yang menyatakan bahwa kualitas produk berpengaruh positif signifikan terhadap citra merek

Temuan penelitian menjelaskan bahwa keputusan pembelian dipengaruhi oleh kualitas produk dan sebagian oleh citra merek. Sehingga, untuk meningkatkan keputusan pembelian maka kualitas produk dan citra merek penting untuk ditingkatkan. Terkait kualitas produk, handphone Nokia belum memiliki spesifikasi yang sesuai dengan keinginan konsumen. Perusahaan harus melakukan market research agar mendapatkan ide atau pertimbangan dalam penambahan spesifikasi yang cocok dan pantas disatukan pada produk handphone Nokia. Dalam pelayanannya, Nokia juga belum memberikan kemudahan bagi konsumennya. Oleh karena itu, perusahaan perlu bekerja sama dengan berbagai vendor handphone Nokia baik penjualan maupun jasa sparepart, service, dan jaminan asuransi dengan cara memperbanyak kerjasama dengan mereka, dengan ini konsumen akan mudah memperoleh pelayanan yang dibutuhkan.

\section{SIMPULAN DAN SARAN}

Berdasarkan permasalahan penelitian, tujuan, hipotesis, dan hasil pembahasan maka dapat disimpulkan bahwa kualitas produk berpengaruh positif dan signifikan terhadap keputusan pembelian. Peningkatan kualitas produk akan meningkatkan keputusan pembelian konsumen.

Kualitas produk berpengaruh positif dan signifikan terhadap citra merek. Peningkatan kualitas produk akan meningkatkan citra merek yang dirasakan di benak konsumen. 
Citra merek berpengaruh positif dan signifikan terhadap keputusan pembelian. Citra merek yang meningkat yang semakin dirasakan oleh konsumenakan meningkatkan keputusan pembelian.

Citra merek memediasi hubungan kualitas produk dengan keputusan pembelian. Hal ini memiliki makna bahwa tanpa adanya citra merek, kualitas produk tetap dapat mempengaruhi keputusan pembelian. Sedangkan dengan adanya citra merek walaupun memberikan dampak dalam upaya untuk meningkatkan keputusan pembelian, citra merek memiliki peran yang besar untuk lebih meningkatkan keputusan pembelian.

Berdasarkan hasil penelitian dan kesimpulan, berikut ini beberapa saran untuk meningkatkan keputusan pembelian melalui kualitas produk dan citra merek.

Kualitas produk perlu ditingkatkan lagi. Hal yang perlu ditingkatkan adalah spesifikasi pada produk handphone Nokia dan kemudahan pelayanan produk tersebut sehingga handphone Nokia memiliki nilai yang produk yang baik. Hal tersebut akan berdampak pada citra merek produk tersebut yang pada akhirnya akan mudah dikenali dan diingat oleh konsumen. Karena dalam mencari informasi tentang produk handphone Nokia yang dilakukan konsumen masih kurang, maka perusahaan harus menyediakan informasi yang menyeluruh disegala media, jelas dan mudah dipahami.

Bagi peneliti selanjutnya, diharapkan dapat meneliti dengan variabelvariabel di luar variabel yang telah diteliti ini agar memperoleh hasil yang lebih bervariatif yang dapat berpengaruh terhadap keputusan pembelian handphone. 
Selain itu menambahkan jumlah sampel, mencari lebih luas ruang lingkup penelitian tidak hanya di Kota Denpasar.

\section{REFERENSI}

Ackaradejruangsri, Pajaree. (2013). The effect of product quality atttributes on Thai's consumer buying decisions. Journal of Asia Pacific Studies, Vol. 3, No. 3, pp. 14-24.

Alma, B. (2011). Manajemen Pemasaran dan Pemasaran Jasa. Bandung: Alfabeta

Anggar Purna Putra, Krisnasakti. (2012). Analisis pengaruh harga, kualitas produk, dan promosi terhadap keputusan pembelian sepeda motor honda (studi kasus pada konsumen di kota semarang). Skripsi. Semarang: Fakultas Ekonomi dan Bisnis, Universitas Diponegoro. Www.eprints.undip.ac.id

Cannon, J.P., William D., Perreault, Jerome., McCarthy.(2008). Pemasaran Dasar: Pendekatan Manajemen Global. Jakarta: Salemba Empat.

Ferrinadewi, E. (2008). Merek dan Psikologi Konsumen. Yogyakarta: Graha Ilmu

Ghozali, Imam. (2014). Partial least squares konsep: Metode dan aplikasi menggunakan porgram warp PLS 4.0. Semarang: Universitas Diponegoro.

Hair, J.F., William C.B., Barry J.B., and Rolph E.A. (2011). Multivariate Data Analysis. Prentice Hall: Pearson

Hanaysha, J., Haim H., Noor H., and Abdul G. (2014). Direct and indirect effects of product innovation and product quality on brand image: Empirical evidence from automotive industry. International Journal of Scientific and Research Publications, Vol. 4, No. 1, pp. 1-7.

Horvath, C., and Marcel V.B. (2015). The role of brands in the behaviour and purchase decisions of compulsive versus noncompulsive buyer. European Journal of Marketing. Vol. 49, No. 1, pp. 2-21.

Irawan dan Edwin J. (2013). Analisis pengaruh kualitas produk terhadap loyalitas melalui kepuasan sebagai variabel intervening pada pelanggan restoran por kee surabaya. Jurnal Manajemen Pemasaran, Vol. 1, No. 2, pp. 1-8

Kalicharan, H.D. (2014).The effect and influence of country-of-origin on consumer's perception of product quality and purchasing intentions. International Business and Economic Research Journal, Vol. 13, No. 5, pp. 897-902.

Kotler, Philip and Garry Armstrong. (2008). Prinsip-Prinsip Pemasaran. Jakarta: Erlangga. 
Kotler, Philip. (2009). Manajemen Pemasaran. Jakarta: Erlangga.

Kurtkoti, A. (2016). Factors influencing consumer buying decision process for different products and brands. Journal of Management and Research, Vol. 6, No.1, pp. 40-59.

Lin, Y.L., and Chun-Shuo C. (2006). The influence of the country-of-origin image, product knowledge and product involvement on consumer purchase decisions: An empirical study of insurance and catering services in Taiwan. Journal of Consumer Marketing, Vol. 23, No. 5, pp. 248-265.

Malhotra, N.K. (2012). Basic Marketing Research: Intergration Of Social Media. New Jersey: Pearson

Megarita, G., dan Tony S. (2014). Pengaruh kualitas produk terhadap citra merek dan dampaknya terhadap perilaku pembelian produk susu merek ultra milk di Jakarta Utara. Jurnal Manajemen Pemasaran, Vol. 4, No. 1, pp. 57-69

Momani, R.A. (2015). The impact of brand dimension on the purchasing decision making of the Jordanian consumer for shopping goods. International Journal of Business and Social Science, Vol. 6, No. 7, pp. 149-168.

Mowen. (1995). Perilaku Konsumen dan Komunikasi Pemasaran, Jakarta: karangan Sutisna.

Nasution, A.H. (2008). Perencanaan dan Pengendalian Produksi. Yogyakarta: Graha Ilmu

Nazir, M. (2003). Metode Penelitian. Jakarta: Salemba Empat

Rajagopal. (2006). Insights from research brand excellence: Measuring the impact of advertising and brand personality on buying decisions. Measuring Business Excellence, Vol. 10, No. 3, pp. 56-65.

Schiffman dan Kanuk. (2004). Perilaku Konsumen. Jakarta: Prentice Hall

Sihabudin. (2015). Pengaruh kualitas produk dan promosi terhadap citra merek handphone Samsung. Jurnal Manajemen dan Bisnis, Vol. 1, No. 1, pp. 1736

Shaharudin, M.R., Suhardi W.M., Anita A.H., Maznah W.O., and Etty H.H. (2011). The relationship between product quality and purchase intention: The case Malaysia's national motorcycle/scooter manufacturer. African Journal of Business Management, Vol. 5, No. 20, pp. 8163-8176.

Shareef, M.A., Uma K., and Vinod K. (2008). Role of different electroniccommerce (EC) quality factors on purchase decision: A developing country perspective. Journal of Electronic Research, Vol. 9, No. 2, pp. 92113.

Simamora, B. (2004). Riset Pemasaran. Jakarta: Gramedia Utama 
Sugiyono.(2004). Metode Penelitian Bisnis. Bandung: CV. Alfabeta.

Tamunu, M., Ferdinand T. (2014). Analyzing the influence of price and product quality on buying decision honda matic motorcycles in Manado. Journal $E M B$, Vol. 2, No. 3, pp. 1255-1263.

Tjiptono, F. (2009). Strategi Pemasaran. Yogyakarta: Andi

Walter, A., Muller T.A., Helfert G., and Ritter T. (2003). Functions of industrial supplier relationship and their impact on relationship quality. Industrial Marketing Management, Vol. 32, No. 1, pp: 59-69.

Yoo, B., Donthu N., and Lee S. (2000). An examination of selected marketing mix elements and brand equity. Academy of Marketing Science, Vol. 28, No. 2, pp. 195-212. 